DOI: $10.17805 /$ zpu.2015.4.24

\title{
Measure for Measure - a play by Shakespeare and Dostoevsky (Globe, 2012)
}

\author{
A. MARTIROSYAN \\ (INDEPENDENT SCHOLAR, ARMENIA)
}

The paper examines the creativity and message involved in the adaptation and appropriation of Shakespeare in the Russian-language production of Shakespeare's "Measure for Measure" ("Mera za meru") staged by Moscow's Vakhtangov State Academic Theatre company at Shakespeare's Globe Theatre in London in 2012.

It is possible to argue that one and the same production can have identifiable elements of both adaptation and appropriation and that these creative genres can co-exist, in varying degrees and with different emphasis, in the same context. In Butusov's "Mera za meru", the appropriation of Angelo and the Duke is climac-tic - both characters are played by the same actor. It will be further argued that Butusov's production is owned, Russianised and represented through a Dostoevskian lens. More than any other Shakespeare play, "Measure for Measure" is the one that is resonantly Dostoevskian in view of the philosophical, moral and existential issues it raises, and Butusov's production makes it ring bells.

Keywords: Shakespeare; Dostoevsky; Russian studies; Shakespeare studies; Measure for Measure; Yuri Butusov; Vakhtangov Theatre; adaptation; appropriation

$\mathrm{T}$ here is increasing open-mindedness about the possibilities in interpreting Shakespeare on the stage and on the page. Spatial, geographic, temporal, racial, cultural, thematic, visual and gender adjustments of Shakespeare's text are the most observable markers of modern day adaptations. Scholars and critics have tried to keep pace with the variety of form and the extent of adaptations, by adjusting, implementing and redefining terminology to precisely describe the various processes of creativity involved. Adaptation is only one term among several dozens. As Linda Hutcheon observes, "A doubled definition of adaptation as a product (as extensive, particular transcoding) and as a process (as creative reinterpretation and palimpsestic intertextuality) is one way to address the various dimensions of the broader phenomenon of adaptation" (Hutcheon, 2006: 22).

The term adaptation is identified, clashed and compared with the term appropriation. Some critics see adaptation as a default term, recognise the subtlety in the other terms and make an intuitive choice according to the context (e.g., D. Lanier (Lanier, 2002), J. Sanders). Others differentiate between the two and suggest new ones, but more with regard to descriptive terminology and media rather than to different creative genres with semantic encoding (e.g., M. Garber, J. Kristeva). Even though Julie Sanders often uses the terms inter- 
changeably, she acknowledges the creative difference, "There are many ways in which both the practice and the effects of adaptation and appropriation intersect and interrelate, yet it is equally important to maintain some clear distinctions between them as creative activities" (Sanders, 2006: 26).

If it is possible to tell a story by Shakespeare's story, the term 'adaptation' automatically assumes an almost antonymic meaning. An adaptation can tell a story by the original by offering a version of interpretation that can be personal, subjective, justifiable or not; and this can mean both reading beyond the text and reading into the text. Appropriation is another author's attempt to get an extra message across (with varying connotational load) alongside it, which can be either in parallel with or in contrast to what is explicit or indeed, implicit, in the first text. As Christy Desmet puts it, "acts of appropriation, although they articulate where the author 'stands' in relation to the object of appropriation, can be intensely personal as well as political" (Desmet, 1999: 7). Roughly put, appropriation is an "extreme adaptation'. On the one hand, appropriation can align with adaptation if the 'extra message' is not objectively readable or emphasised and remains on the level of subjective appreciation by the receptor; on the other hand, appropriation can go beyond the limit where the association with the first text/author/production is almost lost or loose enough not to view the two texts as parallels. A creative product can be termed either an adaptation or appropriation depending on the extent to which the text has been owned by the second author. Moreover, the message is not always linear and the same text can be both an adaptation and appropriation.

Below I look at the creativity and message conveyed by the production of Shakespeare's Measure for Measure which was staged at Shakespeare's Globe Theatre in London in 2012 by the Vakhtangov State Academic Theatre of Russia, as part of the Globe to Globe project. Within the context of Yuri Butusov's Mera za meru (Measure for Measure) staged at the Globe, it is possible to argue that one and the same production can have elements of both adaptation and appropriation and that these creative genres can co-exist, in varying degrees and with different emphasis, in the same context.

Shakespeare's 'problem plays' - as most of his plays indeed - are vulnerable to political interpretations. Mounting a Shakespeare production by adapting it to convey the current or historical political ambience or get a political message across has been common practice in non-English productions as comfortably as in the Anglo-American counterparts. What makes Butusov's production stand out is his stress on the philosophical - rather than political - message. More than any other Shakespeare play, Measure for Measure is the one that so clearly resonates as Dostoevskian. It is a morality play where Shakespeare is exploiting the moral codes more than anything else. Russian literature is deeply concerned with morality, moral ideal, existential issues, self-pity, self-empowerment, inexplicable melancholy, internal conflicts in the human soul and endless philosophical catechism with the self. In an interview at the Globe, Butusov points out that Measure for Measure is not among the popular Shakespeare plays in Russia (Olive, 2012). Yet no other Shakespeare play could possibly have been a better choice for a Russian theatrical company to perform on the Globe-al stage than Measure for Measure. Butusov realised it and accentuated the Russianness in his production of the play. Building on the existential axis of the play as a search for a moral ideal that only finds its inner corruption, Butusov 'painted' as much as produced Shakespeare's Measure for Measure. He applied 'space of tragedy' in his production, which is in accord with the Russian philosophical tradition. The stage resembled a cosmos where everything was fleeting. The characters were forced into action by other char- 
acters blowing wind. The open stage of Shakespeare's Globe helped to create a spacelike environment and convey the philosophical spirit of this subtle production. Evgeniya Kregzhde expressed her admiration of the naturalistic opportunity that The Globe rendered for their performance (Kregzhde, 2012).

Michael Billington notes in his review that at times the link with Shakespeare blurred (Billington, 2012). But those times were also when the performance most explicitly flew in the Russian literary and philosophical tradition. Kregzhde, who played Isabella, writes that Russian Londoners greeted them with cheers before the start of the show and praised Vladimir Beldiyan for playing Claudio in the vein of Alyosha Karamazov (Kregzhde, 2012). However, Kevin Quarmby, whose view I share, found in Beldiyan's portrayal of Claudio a looming perspective of male power and oppression of women. He writes in his review, "Berdinskikh's representation of Juliet's helplessness served to emphasise the phallocentric power of the play's male protagonists; even in chains and led to prison, Claudio commanded dutiful obedience from his besotted devotee" (Quarmby, 2013: 49).

Kregzhde's Isabella was overly saintly and portrayed as an embodiment of innocence. Butusov lived up to Shakespeare's text, indeed, too precisely, in casting Isabella. Rare reviewers, like Billington, read disguised lure in Kregzhde's modest outfit — long skirt, white shirt with an oversized blazer. "But there seems to be a touch of unholy flirtiness in Isabella's first appearance, clad in crisp white blouse and long skirt, in Angelo's office" (Billington, 2012). Butusov emphasises the purity in Kregzhde's teenage-like Isabella, genuinely naïve, and even childish, a pure soul facing Sonya's fate of prostituting her body in Crime and Punishment.

What makes Butusov's production a distinct appropriation of Shakespeare's work is express in the portrayal of the Duke and Angelo by the same actor. The merging of the two lead protagonists may sound absurd and impossible, especially in anticipation of the final scene, but the message such a twist conveyed made the adaptation of the ending not less but more powerful. The striking, unconcealed similarity between Angelo and the Duke was reinforced by parallel scenes which mounted in the final scene of Vincentio and Isabella being a deliberate duplication of the earlier scene between Angelo and Isabella.

Opinion is divided among Shakespeare scholars regarding the goodness or badness of Angelo and the Duke. Some take Shakespeare's text at surface value - Angelo as the evil deputy and the Duke as the moral saviour. In such interpretations, the Duke is usually the Christ-like figure. George Wright is especially defensive of the Duke's intentions. He criticises the "viewers and readers of Measure for Measure" for having "in recent years taken pleasure in mocking the Duke..." (Wright, 2012: 246). Wright sees the Duke's character as "entirely benign" and through a close reading of Shakespeare's text attempts to justify his actions (ibid). Ewan Fernie's reading of the Duke and Angelo stands in effective contrast to the above view. Fernie sees in the Duke a moral charlatan and is more sympathetic to Angelo's desires as possible, which he views in the context of good versus evil, demotic versus holy. "It's Shakespeare's intimate portrayal of Angelo's tragedy of desire which has the power to get under my skin and disturb my moral self-conceit. It's Angelo whom I recognise. It's true he starts out from somewhere beyond sympathy (but isn't that somewhere we all have stood?)" (Fernie, 2013: 198-199). Such a compelling reading can be textually justified if we re-appreciate Angelo's self-analysis at II.ii and the Duke's quite explicit expression of his reason for appointing Angelo to bring in justice into the corrupted city. This could hardly sound an honest deed, yet it is often overlooked in the 'Duke of dark corners' (IV.iii.148; Shakespeare, 1991: 166) criticism: 
I do fear, too dreadful.

DUKE

Sith 'twas my fault to give the people scope,

'Twould be my tyranny to strike and gall them

For what I bid them do: for we bid this be done

When evil deeds have their permissive pass

And not the punishment. Therefore indeed, my father,

I have on Angelo imposed the office,

Who may, in th'ambush of my name strike home,

And yet my nature never in the fight

To do it slander.

(I.iii.35-44; ibid: 95)

Butusov read this moral controversiality in both characters. So does Charles Marowitz in his appropriation of Measure for Measure where the final scene is significantly adapted - with the Duke and Angelo as two corrupt politicians mocking in private the common people and Isabella, the latter sent to prison by the Duke (Marowitz, 2000). But if Marowitz's interpretation of Angelo and Vincentio is political, Butusov's interpretation of the two characters is on moral, existential and psychological basis, made more poignant through the doubling of the actor (Sergey Epishev) as both Vincentio and Angelo. Butusov adopted, adapted and appropriated Shakespeare's Duke and Angelo - this is the most Russianised, the most Dostoevskian feature of Butusov's production. Whether Butusov intended an implicit allusion or not, his technique reminds of Dostoevsky's Double where it is never clear whether there are two characters or one character with split personality, but the story is psychologically and comically profound, almost tragic.

The list of director Yuri Butusov's productions includes a prevailing portion of Dostoevsky. The same cast had been simultaneously involved in a production of Dostoevsky's Demons when Mera za meru first premiered in Moscow in 2010. Unsurprisingly, Epishev had played Stavrogin, Dostoevsky's dark, morally ambiguous Hamletian hero. In their respective reviews of the production, Kevin Quarmby and Evgeniya Tropp (in her review of the original launch of the production in Moscow in 2010) refer to Ephishev as performing three parts (Quarmby, 2013: 48; Tropp, 2010). Indeed, the physical appearance of the actor in all three parts, as Vincentio, Angelo and Friar Lodowick, brought home similarities which text alone cannot convey. By manipulation bearing and demeanour, Epishev managed to shar-pen the edges of the friar-Duke as a third, morally ambiguous character. As Quarmby subtly points out: "It was, however, in disguise as Friar Lodowick that Epishev's physicality offered the most striking visual analogue. In black-hooded habit, Epishev appeared more Mephistophelean opportunist than ducal manipulator" (Quarmby, 2013: 48). And when in the prison scene he kissed Juliet's head from behind, Lodowick-DukeEpishev appeared as a looming giant rather than a comforting holy man to this childish, tiny Juliet. Angelo's sexual frustration and his shameful pleasure in evil-doing reminded of Stavrogin, his suppressed virginal sexuality of epileptic Myshkin. The benevolent, well-wishing Duke (re)arranging everyone's life was a parallel to the opposite reading of Dostoevsky's 'Christ-like idiot' as a malicious calculating mountebank, evoking holy aversion - a devil in a holy man's uniform. The three-fold character casting of Epishev, each equally protruding, might be described by what Harold Bloom has effectively said about "the strong poet" who "peers in the mirror of his fallen precursor and beholds neither the precursor nor himself but a Gnostic double, the dark otherness or antithesis that both he and the precursor longed to be, yet feared to become" (Bloom, 1979: 147). 
Desmet believes that "something happens when Shakespeare is appropriated, and both the subject (author) and object (Shakespeare) are changed in the process" (Desmet, 1999: 4). The outstanding merit of Mera za meru is the way Butusov used the visual and physical advantages of a live theatrical production both to achieve cultural appropriation and explore universal existential questions lurking beyond Shakespeare's disturbing play. The English auditor may have missed the depth and extent of the Russian literary-philosophical interference in the production, or the Russian monolingual Shakespeare amidst the myriad associations with the Russian mindset. But there is universal depth and existential power in the message Butusov strove to release in his unique, cross-cultural, naturalistic and expressionistic interpretation of the play - that surely would have managed to speak to everyone. By overstressing the morality issue Shakespeare focuses on in Measure for Measure, Butusov's production became more than a Russian-language adaptation. Through synonymising Vincentio and Angelo, Butusov challenged Shakespeare's text and the audience, and successfully so, as he offered a perspective on good, evil, saintliness and demonism by visually replacing the 'versus' between those pairs of concepts with an 'and'.

Gary Taylor daringly speculates, "The collapse of Shakespeare is hard to imagine. But then, who could have imagined how easily the Berlin Wall would collapse? Who could have imagined, twenty years ago, the shrinking of the Soviet Union?" (Taylor, 1999: 205). Still, as long as the 'Soviet' country's appropriation of Shakespeare to match the spirit of their own genius, Dostoevsky, makes sense on Shakespeare's very own stage, the collapse of either of them is hard to imagine.

\section{REFERENCES}

Billington, M. (2012) Measure for Measure - review. Shakespeare's Globe, London. The Guardian. April 25. [online] Available at: http://theguardian.com/stage/2012/apr/25/ measure-formeasure-review [archived in WebCite] (accessed 25.08.2015).

Bloom, H. (1979) The anxiety of influence: A theory of poetry. Oxford, Oxford University Press. $157 \mathrm{p}$.

Desmet, C. (1999) Introduction. In: Shakespeare and appropriation / ed. by C. Desmet and R. Sawyer. London ; New York, Routledge. 240 p. Pp. 1-12.

Fernie, E. (2013) The demonic: Literature and experience. London ; New York, Routledge. 312 p.

Hutcheon, L. (2006) A theory of adaptation. New York ; London, Routledge. 232 p.

Kregzhde, E. (2012) O gastroliakh so spektaklem «Mera za meru» v Londone [On "Measure for Measure" tour in London]. Teatr im. Evgeniia Vakbtangova [Yevgeny Vakhtangov Theatre]. June 1. [online] Available at: http://vakhtangov.ru/mediabox/interview/press/27198 [archived in WebCite] (accessed 25.08.2015). (In Russ.).

Lanier, D. (2002) Shakespeare and modern popular culture. Oxford; New York, Oxford University Press. $187 \mathrm{p}$.

Marowitz, C. (2000) Measure for Measure. In: Adaptations of Shakespeare: A critical anthology of plays from the seventeenth century to the present / ed. by D. Fischlin and M. Fortier. London; New York, Routledge. vi, 320 p. Pp. 188-207.

Olive, S. (2012) Year of Shakespeare: Measure for Measure. Blogging Shakespeare. April 27. [online] Available at: http://bloggingshakespeare.com/year-of-shakespeare-measure-for-measure [archived in WebCite] (accessed 25.08.2015).

Quarmby, K. (2013) 'What's mine is yours, and what is yours is mine': Measure for Measure. Vakhtangov Theatre, Moscow. In: Shakespeare beyond English: A global experiment / ed. by S. Bennet and C. Carson. Cambridge ; New York, Cambridge University Press. 317 p. Pp. 48-52.

Sanders, J. (2006) Adaptation and appropriation. London; New York, Routledge. 184 p.

Shakespeare, W. (1991) Measure for Measure / ed. by B. Gibbons. Cambridge ; New York, Cambridge University Press. $213 \mathrm{p}$. 
Taylor, G. (1999) Afterword: The incredible shrinking Bard. In: Sbakespeare and appropriation / ed. by C. Desmet and R. Sawyer. London ; New York, Routledge. 240 p. Pp. 197-205.

Tropp, E. (2010) Dvoinoe postoianstvo zla [The double constancy of evil]. Peterburgskii teatral'nyi zhurnal. September 14. [online] Available at: http://ptj.spb.ru/blog/dvojnoe-postoyanstvozla [archived in WebCite] (accessed 25.08.2015). (In Russ.).

Wright, G. T. (2012) Unmuffling Isabella. In: Shakespeare up close: Reading early modern texts / ed. by R. McDonald, N. D. Nace and T. D. Williams. London, Arden Shakespeare. 377 p. Pp. 245-253.

Submission date: 25.08.2015.

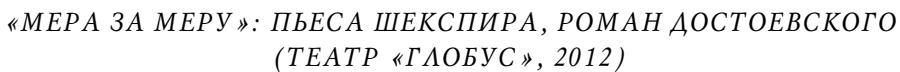

А. О. МАРТИРОСЯН

(НЕЗАВИСИМЫЙ ИССЛЕДОВАТЕЛЬ, АРМЕНИЯ)

Настоящая статья рассматривает влияние Ф. М. Аостоевского на спектакль по пьесе Шекспира «Мера за меру», поставленный Ю. Н. Бутусовым в 2012 г. в лондонском театре «Глобус». Спектакль был впервые поставлен в 2010 г. в Государственном академическом театре имени Е. Б. Вахтангова в Москве.

Автор доказывает, что одна и та же постановка может сочетать в себе черты адаптации и апроприации, которые могут сосуществовать с различной степенью интенсивности, в одном и том же контексте. Отдав роли герцога и Анджело одному актеру, Сергею Епишеву, Бутусов рассматривает пьесу Шекспира сквозь призму вопросов и проблем, которые занимали также и Аостоевского. Они подчеркивают русскую литературную традицию в целом как сосредоточенную на проблемах пространства, бытия и нравственности.

Ключевые слова: Шекспир; Аостоевский; русская литература; шекспироведение; «Мера за меру»; Ю. Н. Бутусов; Театр им. Вахтангова; адаптация; апроприация

\section{СПИСОК АИТЕРАТУРЫ}

Крегжде, Е. (2012) О гастролях со спектаклем «Мера за меру» в Иондоне [Электронный ресурс]// Театр им. Евгения Вахтангова. 1 июня. URL: http://vakhtan-gov.ru/mediabox/interview/ press/27198 [архивировано в WebCite] (дата обращения: 25.08.2015).

Тропп, Е. (2010) Авойное постоянство зла [Электронный ресурс] // Петербургский театральный журнал. 14 сентября. URL: http://ptj.spb.ru/blog/dvojnoe-postoyanstvo-zla/ [архивировано в WebCite] (дата обращения: 25.08.2015).

Billington, M. (2012) Measure for Measure - review. Shakespeare's Globe, London [Электронный ресурс]// The Guardian. April 25. URL: http://theguardian.com/stage/ 2012/apr/25/measurefor-measure-review [архивировано в WebCite] (дата обращения: 25.08.2015).

Bloom, H. (1979) The anxiety of influence: A theory of poetry. Oxford : Oxford Univer-sity Press. $157 \mathrm{p}$.

Desmet, C. (1999) Introduction // Shakespeare and appropriation / ed. by C. Desmet, R. Sawyer. London; New York : Routledge. 240 p. P. 1-12.

Fernie, E. (2013) The demonic: Literature and experience. London; New York : Routledge. 312 p.

Hutcheon, L. (2006) A theory of adaptation. New York ; London, Routledge. 232 p.

Lanier, D. (2002) Shakespeare and modern popular culture. Oxford ; New York : Oxford University Press. 187 p.

Marowitz, C. (2000) Measure for Measure // Adaptations of Shakespeare: A critical anthology of plays from the seventeenth century to the present / ed. by D. Fischlin, M. For-tier. London ; New York : Routledge. 320 p. P. 188-207.

Olive, S. (2012) Year of Shakespeare: Measure for Measure [Электронный ресурс]// Blogging Shakespeare. April 27. URL: http://bloggingshakespeare.com/year-of-shakespeare-measure-formeasure [архивировано в WebCite] (дата обращения: 25.08.2015). 
Quarmby, K. (2013) 'What's mine is yours, and what is yours is mine': Measure for Measure. Vakhtangov Theatre, Moscow // Shakespeare beyond English: A global experiment/ ed. by S. Bennet, C. Carson. Cambridge ; New York : Cambridge University Press. 317 p. Pp. 48-52.

Sanders, J. (2006) Adaptation and appropriation. London ; New York : Routledge. 184 p.

Shakespeare, W. (1991) Measure for Measure / ed. by B. Gibbons. Cambridge ; New York : Cambridge University Press. 213 p.

Taylor, G. (1999) Afterword: The incredible shrinking Bard // Shakespeare and appropriation / ed. by C. Desmet, R. Sawyer. London ; New York : Routledge. 240 p. P. 197-205.

Wright, G. T. (2012) Unmuffling Isabella // Shakespeare up close: Reading early modern texts / ed. by R. McDonald, N. D. Nace, T. D. Williams. London : Arden Shakespeare. 377 p. P. 245-253.

Аата поступления: 25.08.2015 2.

Мартиросян Ани Оганесовна - доктор философии (PhD), независимый исследователь, редактор, переводчик. Адрес: 0069, Армения, г. Ереван, ул. Аавида Анахта, 19-13. Тел.: +374 98 555026. Эл. aspec: shakespeareality@gmail.com

Martirosyan Annie Oganesovna, $\mathrm{PhD}$ in Philology, independent scholar, freelance editor, translator. Postal address: 19-13 David Anhaght St., 0069 Yerevan, Armenia. Tel.: +374 98 555026. E-mail: shakespeareality@gmail.com 